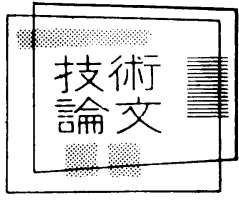

\title{
水平気流中に置かれたワイヤメッシュ デミスタの分離特性*
}

\author{
石谷清幹 ${ }^{* *}$. 中西重康 ${ }^{* * *}$ 杉田英昭 ${ }^{* * * *}$
}

Separation Performance of Wire-mesh Demister being held perpendicular to the Horizontai Air Flow

By Seikan Ishigai, Shigeyasu Nakanishi, Hideaki Sugita

In this paper, separation of water droplets from air including water droplets by wire-mesh demisters is investigated through experiments.

Wire-mesh demisters used here are constructed by galvanized iron wires which are held perpendicular to the air flow direction and which have one layer. Moreover, the demisters have three different specific surface area, $11.06,14.43$ and $39.78 \mathrm{~cm}^{2} / \mathrm{cm}^{3}$ respectively. For all of the demisters mentioned above, mean air velocity is varied over the range of 1.0 to $6.0 \mathrm{~m} / \mathrm{s}$, with the size of water droplets being varied over the range of 5 to about $200 \mu \mathrm{m}$.

The values of separation efficiencies of these demisters are larger by those predicted by theoretical analysis which has been presented by A. Bürkholz, et al. or C. Carpenter, et al.

Characteristics of size distribution of water droplets at the inlet and the outlet to the demister, and furthermore resistance coefficients of these demisters are also investigated.

\section{1. まえがき}

気体や蒸気の流れに打ける液滴のエントレインメント は舶用プラントはもとより, 各種工業プラントにおいて 普通よく見られる現象である。しかし，乙れらの液滴は 一般に機械の損傷や製品の質の低下をもたらす。たとえ ば, ボイラの蒸気ドラムからの液滴は蒸気タービンのブ レードのエロージョンやコロージョンの原因となり，ま た，舶用ガスタービンの吸気中に含まれる液滴むタービ ン内部に悪影響を及ぼす。したがって，各種プラントに おいててれらの液滴を除去するために，サイクロン，折 れ板形エリミネータ，ワイヤメッシュデミスタ，ウォッ シャ, エレクトロフィルタ等種々の分離器が使用されて いる．乙れらの分離器はそれぞれその最適使用範囲があ る. そのうち最むよく用いられている折板㭢エリミネ 一タに関して,すでに筆者らはその分離特性を理論的に 解析し ${ }^{1)}$, 空気一水を用いた実験によってその有効性を 検証した ${ }^{2)}$. 一方, このエリミネータと同じ慣性力形分 離器であるワイヤメッシュデミスタは構造が簡単で装置

\footnotetext{
* 原稿受付 昭和 55 年 6 月 25 日 昭和 55 年春季学術講演 (昭和 55 年 5 月 28 日)

** 正会員 大阪大学工学部(吹田市山田上)

*** 大阪大学工学部 (吹田市山田上)

****. 正会員 神戸商船大学 (神戸市東灘区深江南町 5-1-1)
}

Journal of the M.E.S. J., Vol.15, No.12
への取り付けが容易であるうえに，他の分離器と比較し て圧力損失はかなり小さい. また, $1 \sim 10 \mu \mathrm{m}$ の範用の液 滴分離については一般にエリミネータよりも有利である といわれている゙ ${ }^{3)}$. 実際の使用にあたって, このデミス 夕は数 $\mathrm{mm}$ の間隔で $20 \sim 100$ 層で組み立てられて抢り, 垂直上昇気流中に水平に取り付けられているのが普通で ある.

てれまでに多層のデミスタの捕集効率や圧力損失に関 する実験的研究はかなり行われてきているが ${ }^{4)}$ ）, 最む 簡単な 1 層のデミスタの捕集効率や圧力損失, およびデ ミスタによって液滴の粒度分布がどのように変えられる かについてはこれまであまり研究は行われていないよう である、そこで，筆者らは空気－水系の水平気流中に 1 層のデミスタを置き，その前後におけるエントレインメン 卜量を測定するとともに粒径測定む行いデミスタの分離 特性を調べて, これまでに発表されている理論との比較 を行った，さらに，デミスタの玨力損失を測定し，乾燥 時と液滴を噴霧したときの比較を行った.

使用したデミスタは 3 種類で, それぞれワイヤ径やメ ッシュなどを異にしておりてれらの影響についても考察 できるようにデミスタを選んだ。

\section{2. 実験装置および実験方法}

本実験の装置抢よび方法はすでに発表した折れ板形エ 
リミネータの分離性能に関する実験とほぼ同じである. したがって，乙こでは概略を説明するにとどめ，詳細に ついては文献 2)を参照されたい.

2.1 実験装置長さ $4.23 \mathrm{~m}$, 有効断面 $120 \times 120$ $\mathrm{mm}$ の水平ダクトは厚さ $10 \mathrm{~mm}$ の透明アクリル板でで きており，ノズルの噴霧状態やデミスタにおける液滴の 付着状態を観察することができる. 空気はダクト後端に 取り付けたシロッコファンによって吸引流入され，ダク 卜前端に取り付けた JIS 規格による入口ノズルによっ てこの空気流量を測定した。一方，空気に同伴される液 滴はダクト前端から $40 \mathrm{~cm}$ の位置に気流に向けて設けた 噴霧ノズルから加圧ポンプによって発生させた．との液 滴を同伴した空気は $2.5 \mathrm{~m}$ 後方にダクトの断面全体を覆 うようにしてはめ込んだワイヤメッシュデミスタに流入 し，そてで液滴の一部は捕集される.さらに，空気は残 りの液滴を同伴してファンを通り外部へ流出する.また， デミスタ前後のダクト上面には液滴捕獲器および質量流 量測定用液滴捕集器の挿入孔が設けられている.

実験は平均空気速度 $U$ を $1.0 \mathrm{~m} / \mathrm{s}$ から最大 $6.0 \mathrm{~m} / \mathrm{s}$ ま で変化させ,噴霧圧力 $p_{\mathrm{n}}$ む 2,4 および 6 atgの 3 段階に 変えて行った.

2.2 供試デミスタ 使用したデミスタは 1 層で, 3 種類のワイヤメッシュを図 1 に示すようにそれぞれ， 厚さ $5 \mathrm{~mm}$ の 2 枚のアクリル板でできた枠の間に谷 1 枚 はめ込んで固定したものである.

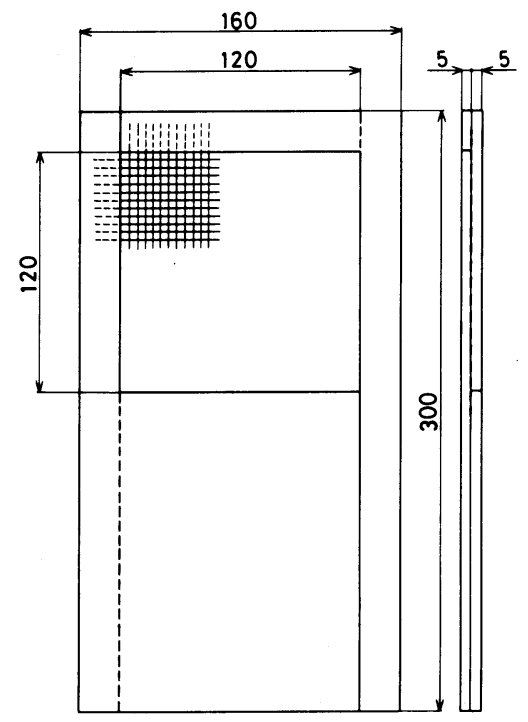

図 1 デミスタの概略図
ワイヤメッシュデミスタは普通, 次式で定義される比 表面積 $a$ とボイドフラクション $\varepsilon$ にっって指定される.

$$
\begin{aligned}
& a=\frac{\text { ワイヤの表面積 }}{\text { デミスタの容積 }} \\
& \varepsilon=1-\frac{\text { ワイヤによって占められる容積 }}{\text { デミスタの容積 }}
\end{aligned}
$$

また，相対投影面積 $p_{1}$ は次式で定義される.

$$
p_{1}=\frac{\text { ワイヤの投影面積 }}{\text { デミタタの投.影面積 }}
$$

3 種類の供試デミスタの要目を表 1 に示すが, No. 1 と No. 2 デミスタは相対投影面積とボイドフラクションは ほとんど同じで，ワイヤ径，比表面積およびメッシュが 異なる. No. 3 デミスタは他のものよりも極端にワイヤ 径を小さくしてメッシュを大きくしている.

2.3 同伴液滴の粒度分布の測定 液滴粒子の寸 法を測定する方法はいろいろ提言されているけれども， 本実験では液浸法を採用して液滴粒子の顕微鏡写真から 直接寸法測定を行った. 液滴は少し劣化させた特 3 号シ リンダ油を塗布したガラス板に捕獲されるが，てのシリ ンダ油は十分な高粘度を有して打り，乙れを塗布したガ ラス板を垂直に立ててもシリンダ油が流下する速度はき わめて遅く、ほとんどての流下速度の影響は無視できた この液滴を受け止めるガラス板は液滴捕獲器 ${ }^{2)}$ の所定の 位置に取り付けられ，背後の押えばねによって固定され る. 捕獲器には $\phi 6.5 \mathrm{~mm}$ の空が気流方向に向かってあ けられており, 前面のシャッタを開けることによって液 滴はこの空を通りガラス板に捕獲される。一方，シャッ タの下端は上流側に曲げられており, シャッタに付着し た液滴が流下して空から内部に入るのを防いでいる・シ ャッタによる液滴の捕獲時間は実験条件に応じて 1 秒か ら 30 秒まで変化させて液滴粒子数密度が過大にならな いようにした．捕獲した液滴の顕微鏡写真は印画紙上に 100 倍に焼き付け， $5 \mu \mathrm{m}$ ごとに粒径区分を設けて寸法 を測定した. したがって，それぞれの区分範囲に含まれ る 1 個の液滴粒子の平均質量 $w_{\mathrm{p}}$ と平均直径 $D_{\mathrm{p}}$ をそれぞ れ次式で定義した。

$$
\begin{aligned}
& w_{\mathrm{p}}=\frac{\rho_{\mathrm{p}}}{5} \int_{D_{1}}^{D_{2}} \frac{\pi}{6} D_{\mathrm{p}}^{3} d D_{\mathrm{p}}=\frac{\rho_{\mathrm{p}}}{120} \pi\left(D_{2}^{4}-D_{1}^{4}\right) \\
& D_{\mathrm{p}}=\left(\frac{D_{2}^{4}-D_{1}^{4}}{20}\right)^{1 / 3}
\end{aligned}
$$

ここで, $\rho_{\mathrm{p}}$ : 液滴の密度, $D_{1}, D_{2}$ : 液滴粒子径区分 の下限および上限の粒径;

2.4 同伴液滴の質量流量の測定 液滴の質量流 量は顕微鏡写真から得られる液滴粒子の直径と個数から

表 1 供試デミスタの要目

\begin{tabular}{|l|l|c|c|c|c|}
\hline デミスタ & ワイヤ径 $D$ & 相対投影面積 $p_{1}$ & ボイドフラクション $\varepsilon$ & 比表面積 $a$ & メッシュ \\
\hline No. 1 & $850 \mu \mathrm{m}$ & 0.30 & 0.765 & $11.06 \mathrm{~cm}^{2} / \mathrm{cm}^{3}$ & 5.03 \\
No. 2 & 650 & 0.30 & 0.766 & 14.43 & 6.51 \\
No. 3 & 300 & 0.38 & 0.702 & 39.78 & 18.14 \\
\hline
\end{tabular}


求めることができるが, 実際には粒径は $5 \mu \mathrm{m}$ 区分で測 定しており, また, 微小液滴は気流の偏向によりガラス 板にあたらずにそれてしまったり, 捕獲されても小さ過 ぎて写真によるカウントが困難である.さらに, 捕獲時 間が 1 秒とか 2 秒といった短時間の場合が多く，その捕 獲時間に誤差が入りやすい等のために本実験では液滴捕 集器 $^{2)}$ にはさんだガーゼに液滴を付着させ,ガーゼの質 量増加を $0.1 \mathrm{mg}$ まで測定できる精密級化学天びんにて 計量することによって質量流量を求めた。なお，ての測 定にあたっては正確にガーゼが液滴を捕集しており，蒸 発の影響による質量変化のないとよをあらかじめ確かめ ている.

\section{3. 実験結果および考察}

\section{1 デミスタ前後における液滴の粒度分布}

デミスタ前後における液滴粒子の顕微鏡写真の一例を 図 2 と図 3 に示す. 図 2 は平均空気速度 $U$ が $5.0 \mathrm{~m} / \mathrm{s}$ で, 噴霧圧力 $p_{\mathrm{n}}$ が 2 atg のときの写真で, 液滴の捕獲時間は いずれも 2 秒である. No. 1 と No. 2 デミスタを比較する とあまり差はみられないが, No. 3 デミスタは他のデミ スタよりあ粒子数密度は小さくなっている. しかし, い ずれのデミスタの場合も液滴の最大粒径はデミスタ前の それと大差はない. 平均空気速度をそのままにして噴霧 圧力を $6 \mathrm{atg}$ まで高めたときの写真を図 3 に示す. 捕獲 時間はすへて 1 秒である. 図 2 に比べて明らかに液滴の 粒子数密度はデミスタ前後とも増えていることが分る. No. 2 デミスタのときの写真はNo. 1 デミスタのときの写
真とほとんど同じであった.なお，後揭の図８に示すよ うに噴霧圧力が高いことは同伴液滴流量が多いことを意 味している。

次に、これらの顕微鏡写真から液滴粒径を測定して求 めたデミスタ前後における液滴の個数ひん度をヒストグ ラムに表わした結果を図 4 に示す.ただし，個数ひん度 $n_{\mathrm{p}}$ は次式で定義される.

$$
n_{\mathrm{p}}=n_{i} / \sum_{i} n_{i}
$$

図 4 は噴霧圧力が 6 atg のときのヒストグラムである が, 他の噴霧圧力の之きもその傾向は全く同じであった。 粒径は先にのべたように $5 \mu \mathrm{m}$ ごとに測定しているが, 図では粒径の分布が一見しやすいように $10 \mu \mathrm{m}$ 間隔でヒ ストグラムを描いている. 各平均空気速度に対してデミ スタ前の液滴粒子のヒストグラムの下方に No. 1, No.2 およびNo. 3 の順にデミスタ通過後の液滴粒子のヒスト グラムをそれぞれ示している. まず，本実験の最小の平 均空気速度である $1.0 \mathrm{~m} / \mathrm{s}$ の場合, 噴霧圧力を変えても ほとんどすべてのデミスタにおいて，デミスタ通過後の $0 \sim 30 \mu \mathrm{m}$ の小粒径液滴個数の占める割合がデミスタ前 のそれに比較して大幅に増加している.したがって，逆 に $40 \mu \mathrm{m}$ 以上の液滴個数の占める割合が減少しており, この傾向は平均空気速度が $2.0 \mathrm{~m} / \mathrm{s}$ の場合にも見られる. しかし, この両方の速度に対しても捕獲液滴の最大粒径 にはほとんよ゙変化はなかった. さらに, 平均空気速度が $3.0 \mathrm{~m} / \mathrm{s}$ になると約 $50 \mu \mathrm{m}$ 以上の粒径の大きい液滴の占 める割合がやや増加してくる. また，乙のときの最大粒
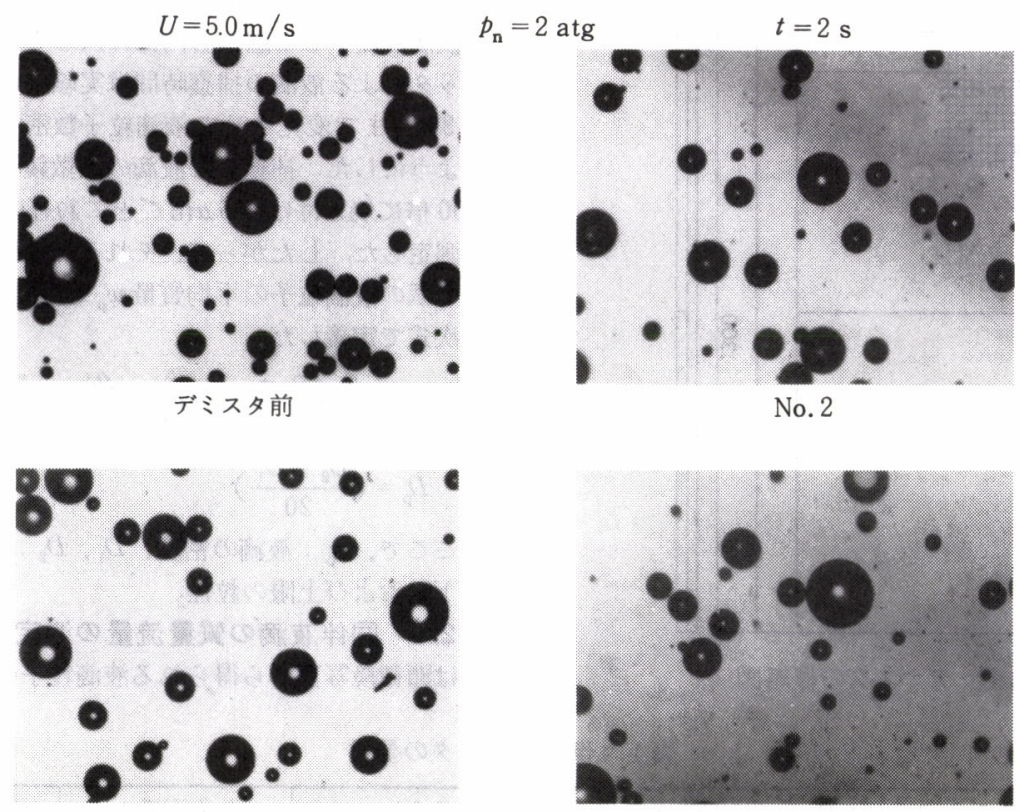

No. 1
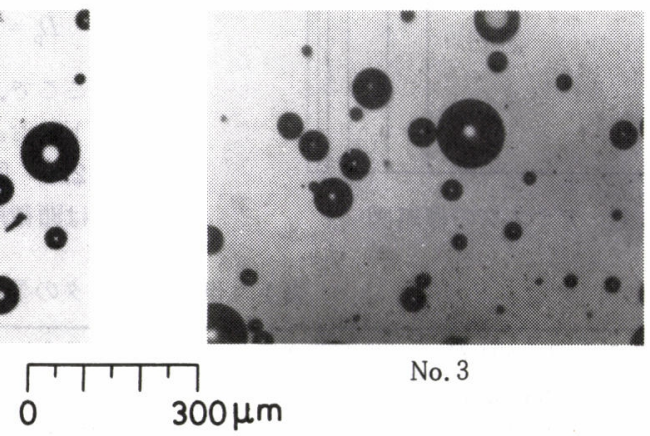

図 2 液滴の顕微鏡写真 


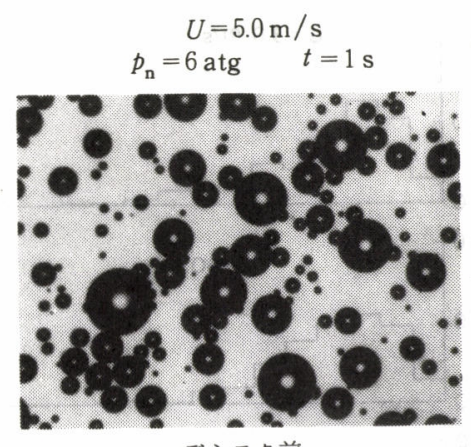

デミスタ前

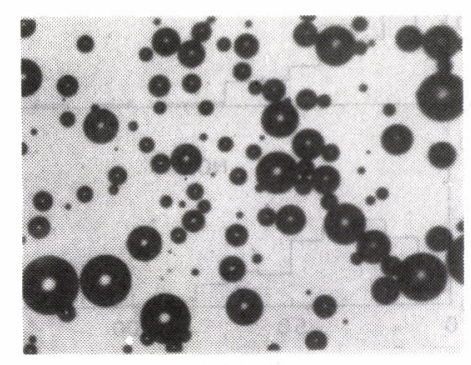

No. 1

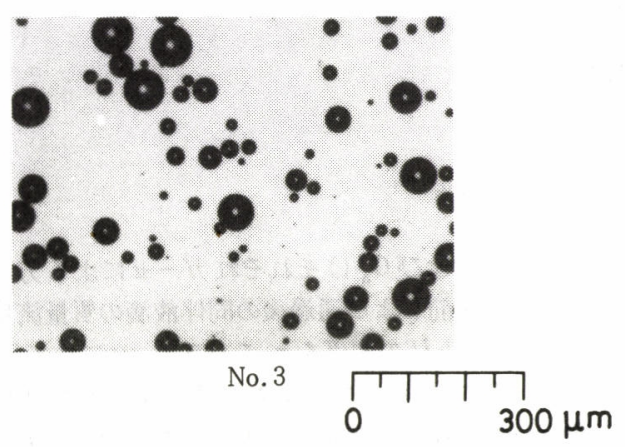

図 3 液滴の顕微鏡写真

径も $100 \mu \mathrm{m}$ を超えるようになり, 再同伴によってデミ スタ前の最大粒径よりも通過後の最大粒径の方が大きい 場合む生じている.

粒度分布を以上のように個数ひん度のヒストグラムで 表わしたが，さらに定量的に粒度分布を解析するために 次式に示す Rosin-Rammler 分布関数を用いた.

$$
R=100 \exp \left(-D_{\mathrm{p}} / D_{\mathrm{e}}\right)^{n}
$$

ここで, $n$ は分布指数で分布のばらつきの程度を表わ している. この nの值はRosin-Rammler 線図の直線の 傾きから求めることができる. $D_{\mathrm{e}}$ は一種の平均粒径で, この式 (7)が成立すれば $R=36.8 \%$ のときの $D_{\mathrm{p}}$ の值が $D_{\mathrm{e}}$ になる. $R$ は積算残留率で, ある粒径 $D_{\mathrm{p}}$ 以上の液滴 の質量が全液滴の質量に対して占める割合である. この 積算残留率 $R$ は式 (8)で定義される質量ひん度 $f_{\mathrm{p}}$ から式 (9)を用いて計算することができる.すなわち,

$$
\begin{aligned}
& f_{\mathrm{p}}=\frac{w_{i}}{\sum_{i} w_{i}}=\frac{n_{i} D_{\mathrm{p} i}^{3}}{\sum_{i} n_{i} D_{\mathrm{p} i}^{3}} \\
& R=1-\sum_{D_{\mathrm{p}}=0}^{D_{\mathrm{p}}} f_{\mathrm{p}}
\end{aligned}
$$

ここで, $w_{i}$ : 粒径が $D_{\mathrm{p} i}$ である液滴の質量, $n_{i}:$ 粒径 が $D_{\mathrm{p} i}$ である液滴の数.

デミスタ前における液滴の積算残留率をRosinRammler 線図上にプロットし, 得られたRosin-Rammler 線図から分布指数 $n$ 之平均粒径 $D_{\mathrm{e}}$ を求めた結果を図 5 に 示す．噴霧圧力によって多少のばらつきはあるが全体之 しては平均空気速度が大きくなるにつれて平均粒径は大 きくなっており，反対に分布指数は小さくなっている. すなわち,デミスタ前において平均空気速度が大きくな ると同伴できる液滴粒径も大きくなり分布の幅む広がっ てくる. しかし, この傾向は平均空気速度か $3.0 \mathrm{~m} / \mathrm{s}$ 付 近まででそれ以上の速度になるとノズルの特性に対応す る分布指数と平均粒径になってしまっている.

次に, 各デミスタ前後における液滴粒子の質量分布の 比較を図 6 亿示す. 平均空気速度は $1.0 \mathrm{~m} / \mathrm{s}$ と $3.0 \mathrm{~m} / \mathrm{s}$ で代表させている. デミスタ通過後に対するRosinRammler 線図はよい直線性を示しているが, デミスタ の種類による区別はあまりはっきりしない. $U=1.0 \mathrm{~m} / \mathrm{s}$ のときは噴霧圧力がいずれの場合にもデミスタ通過後の 直線はデミスタ前のそれよりも最大粒径の点を支点にし て傾きがゆるやかになっており，分布の幅が広がってい るととを示している. そして, $U=3.0 \mathrm{~m} / \mathrm{s}$ になると噴霧 圧力が 4 atg 上 6 atg のときは逆にデミスタ通過後の直 線は最小粒径の点を支点にして傾きが急になっており, 分布の幅が狭くなり分布が均一になっていることを示し ている.いずれの場合も平均粒径の值は小さくなってい る. しかし, $U=3.0 \mathrm{~m} / \mathrm{s}$ で同伴液滴流量の少ない $p_{\mathrm{n}}=$ $2 \operatorname{atg}$ のきはデミスタ後に対して明確な分布の区別が つかず，破線で示す範囲内に点がばらつき直線を引くこ とができなかった。

次に, デミスタ通過後の液滴に対するRosin-Rammler 線図から分布指数之平均粒径を求めてプロットすると図 7 のようになる.これによると全体としてデミスタの種 類によって異なった分布はみられない. 一方, 同伴液滴 の流量に対する影響をみると，噴霧圧力が $4 \mathrm{atg}$ と $6 \mathrm{atg}$ のときは平均空気速度が $3.0 \mathrm{~m} / \mathrm{s}$ 以上で飽和の状態にな っているが噴霧圧力が 2 atg のときは平均空気速度が 4.0 $\mathrm{m} / \mathrm{s}$ 以上でそれが認められる. すなわち, 飽和点は同伴 液滴の流量によって異なることを示している．との飽和 点に達したときの Rosin-Rammler 分布式は各デミスタ とも同じでほぼ次のように表わされる. 

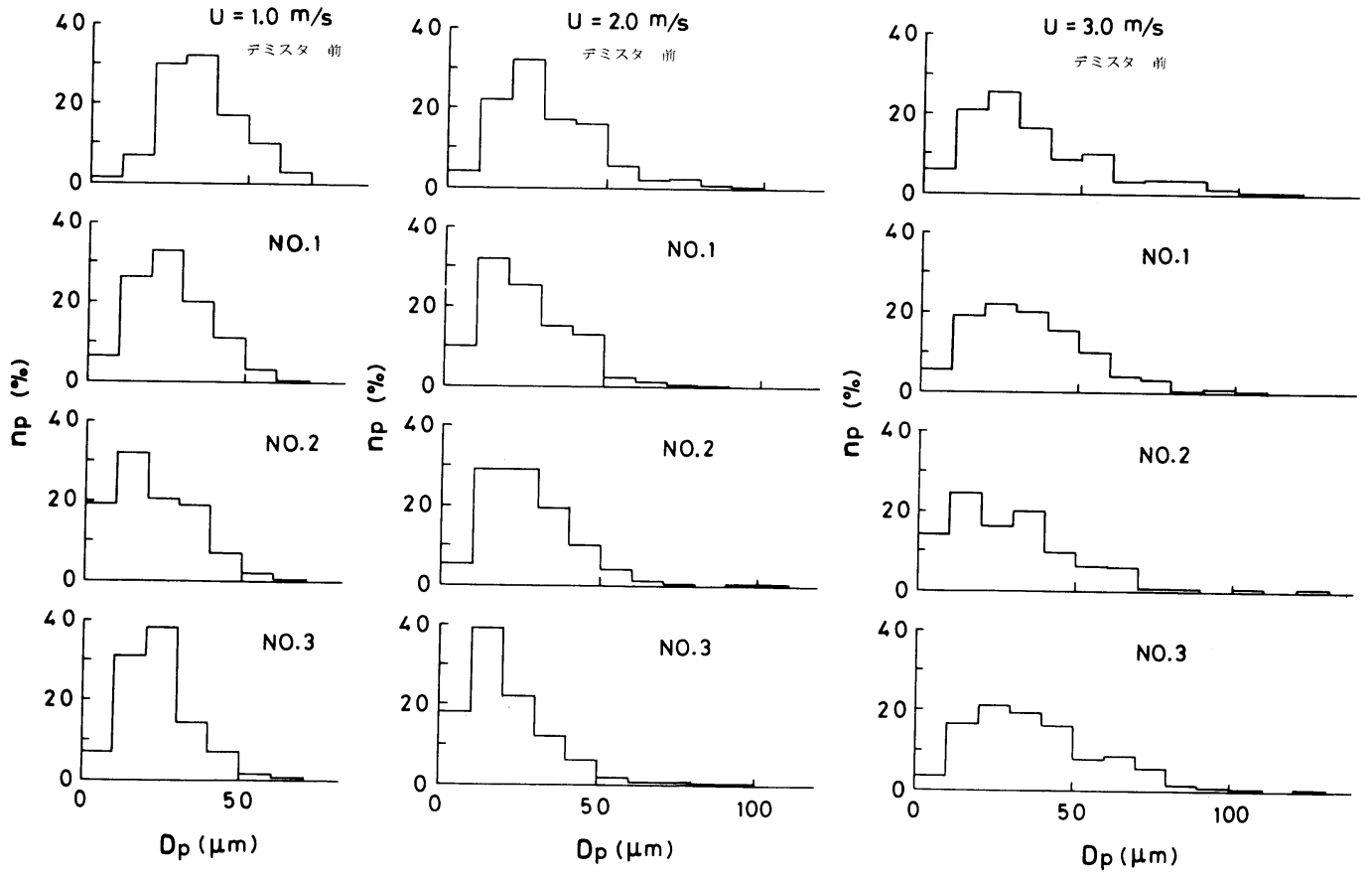

$\left(P_{n}=6\right.$ atg $)$

図 4 液滴の個数ひん度
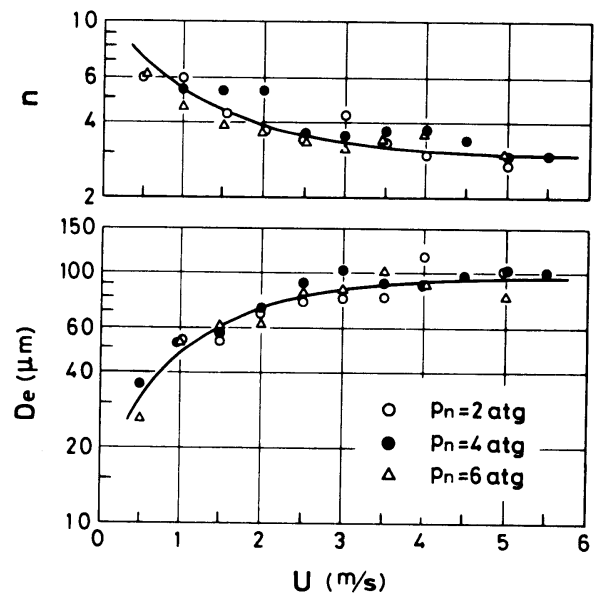

困 5 デミスタ前の $n$ と $D_{\mathrm{e}}$ の值

$$
\left.\begin{array}{ll}
p_{\mathrm{n}}=2 \operatorname{atg} \text { のさき } & R=100 \exp \left(-\frac{D_{\mathrm{p}}}{91.7}\right)^{3.7} \\
p_{\mathrm{n}}=4 \operatorname{atg} \text { のとき } & R=100 \exp \left(-\frac{D_{\mathrm{p}}}{72.1}\right)^{3.8} \\
p_{\mathrm{n}}=6 \operatorname{atg} \text { のとき } & R=100 \exp \left(-\frac{D_{\mathrm{p}}}{71.6}\right)^{3.6}
\end{array}\right\}
$$

\section{2 ワイヤメッシュデミスタの捕集効率}

デミスタの捕集効率 $\eta$ は次式によって定義することが
できる.

$$
\eta=1-\frac{G_{\mathrm{a}}}{G}
$$

ここで，Gおよび $G_{\mathrm{a}}$ はそれぞれガーゼによる方法で 求めたデミスタ前および通過後の同伴液滴の質量流量で ある. 図 8 に $G U$ の関係を $p_{\mathrm{n}}$ をパラメータにして示す. 図 9 は式(11) で計算して求めた捕集効率と平均空気速 度の関係を各噴蓩圧力に対して表わしたもので, デミス タの種類をパラメータにしている. 平均空気速度が 3.0 $\mathrm{m} / \mathrm{s}$ あたりまでは捕集効率は平均空気速度の増加之之 あに急激に増えているが, 平均空気速度がそれ以上にな ると捕集効率は逆にゆっくりと减少し始めている. これ は同図のすべての場合に見られる現象である. この捕集 効率が途中で減少することはワイヤに付着した液滴やメ ッシュの目を覆っている液膜が高速の気流によって再同 伴されるためである. ワイヤメッシュにおける液滴の捕 集状況を観察すると，まず，ワイヤに衝乫した液滴同士 が合体してワイヤに大きな滴となって付着し，ついは 垂直位置のワイヤに沿って流下する，一方，水平位置の ワイヤに付着して大きくなった液滴はやがてワイヤから 離脱するが, 液滴の大きさとメッシュの目の大きさによ ってはその液滴か離脱せずにメッシュの目を覆う液膜之 なる、そして，乙の液滴がデミスタの捕集効率に大きく 寄与している.た亡えば, 図 9 の $U=1.0 \mathrm{~m} / \mathrm{s}$ のときの捕 集効率に注目する之, 流入同伴液滴流量の少ない $p_{\mathrm{n}}=2$ 

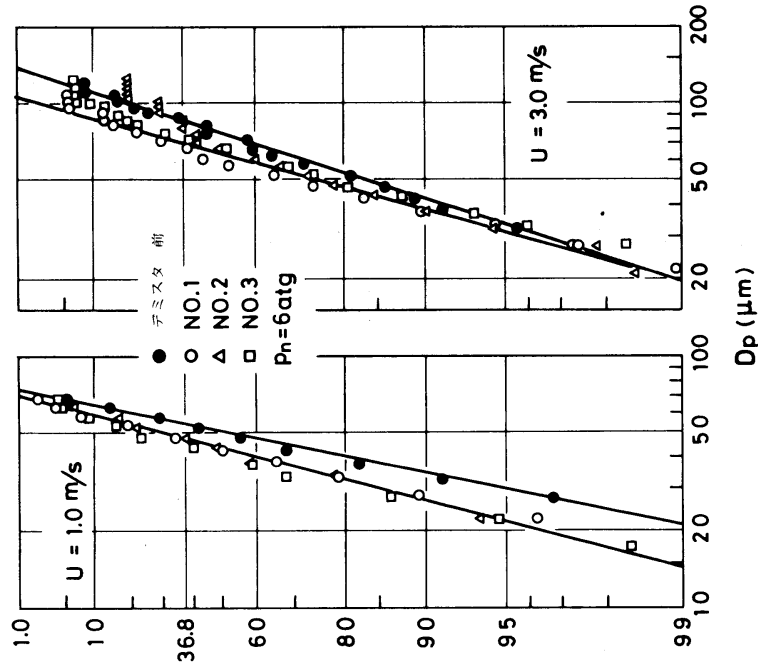

$(\%)$ d

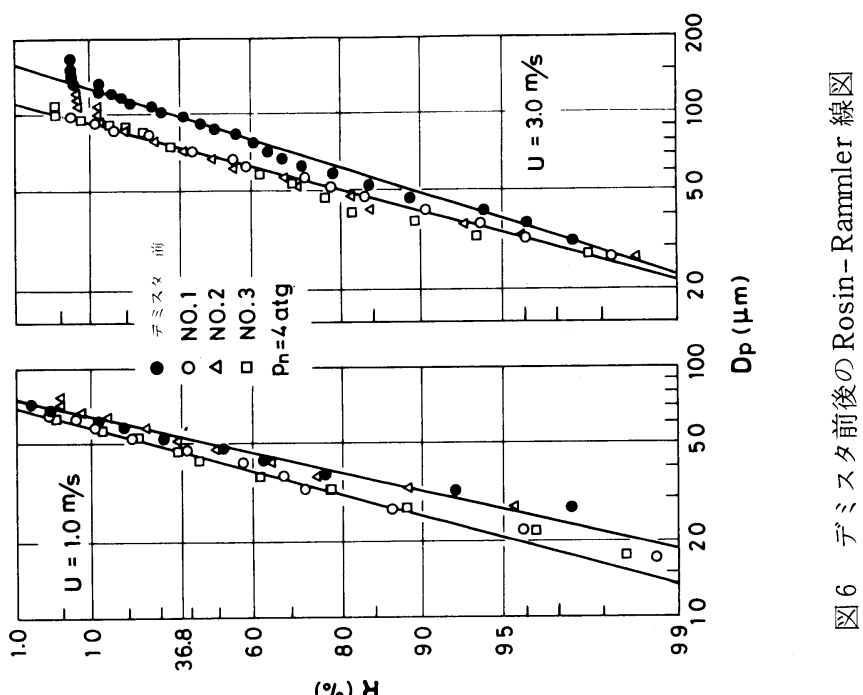

$(\%)$ d

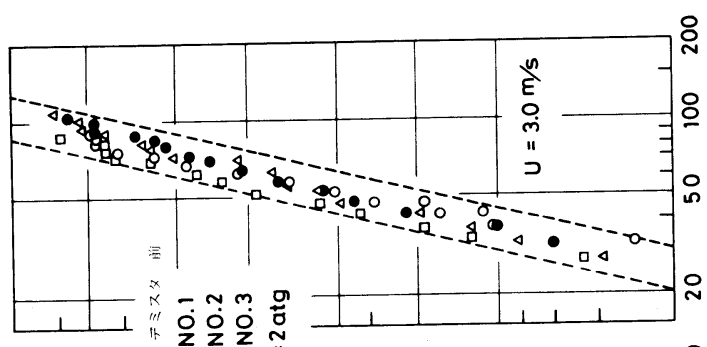
오

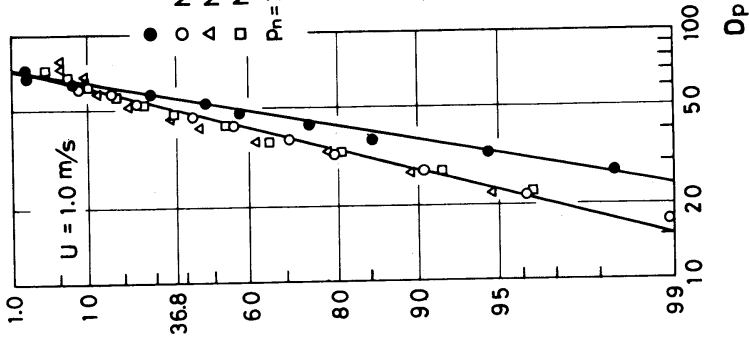

$(\%)$ y 
atg の場合はどのデミスタも液膜が生じなかったが，同 伴液滴流量の多い $p_{\mathrm{n}}=6$ atg の場合はすでにての空気速 度で液膜が生じ始めており，かなり効果は上昇している。 また, No. 2 およびNo. 3 デミスタとメッシュの目の一番大 きいNo.1デミスタとははっきりと捕集効率に差がでてい る. しかし、 $U=3.0 \mathrm{~m} / \mathrm{s}$ になると $p_{\mathrm{n}}=2$ atg の場合も液 膜が生じ, No.1, No. 2 デミスタとNo. 3 デミスタの捕集 効率に差が生じている. このととは他の噴霧圧力の場合 には $U=2.0 \mathrm{~m} / \mathrm{s}$ のときみられる.すなわち，乙の平 均空気速度以上になると No. 3 の目の細かいデミスタは 他のデミスタよりもはるかに液膜が生じやすくなってお り捕集効率が高い。なお，高速域で噴霧圧力の低い方が
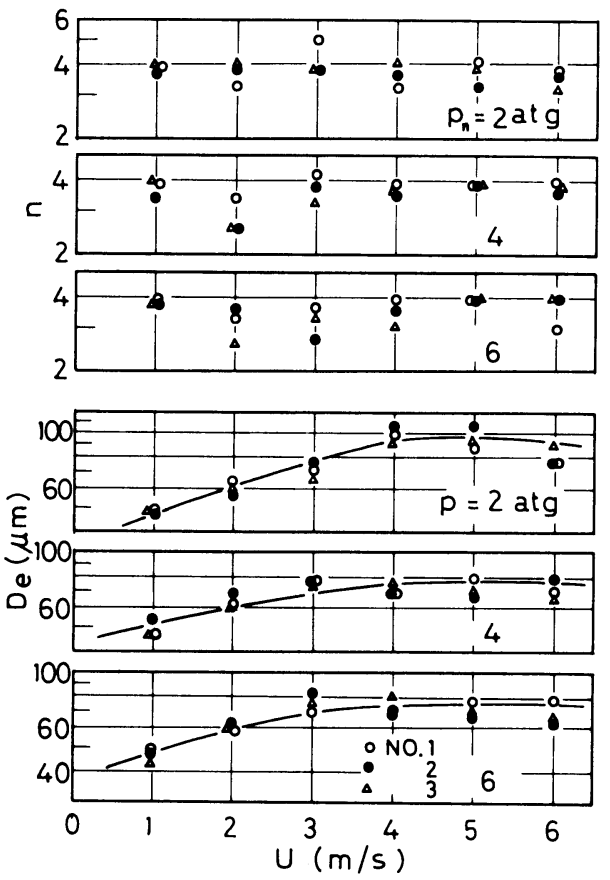

図 7 デミスタ後の $n$ と $D_{\mathrm{e}}$ の值
高効率なのは同伴液滴量が少ないとワイヤや液膜での液 滴の合体する率が低くなり，それだけ長く捕集作用を続 けるとよができるためと考えられる.

次に，ワイヤメッシュデミスタの理論捕集効率につい て考察する．デミスタの理論捕集効率の基礎となる理論 は 1 個の円筒，すなわち，1本のワイヤにおける粒径捕 集効率 $\eta_{\mathrm{d}}^{\prime}$ である.これは図 10 に示すように，液滴を同 伴した空気がてのワイヤに衝突するとき空気は実線で示 されるようにその表面に沿って偏向して流れるが，液滴 粒子は破線で示されるように慣性のためにワイヤ面に衝 突して捕集される.したがってての図の場合， $D^{\prime}$ で示さ れる範囲に存在する液滴はすべて捕集されるからワイヤ

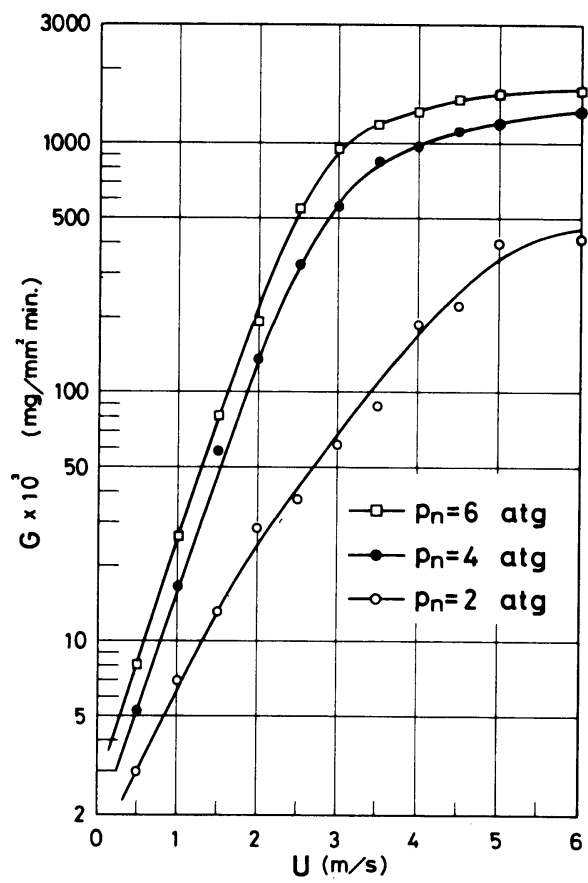

図 8 デミスタ前の同伴液滴質量流量
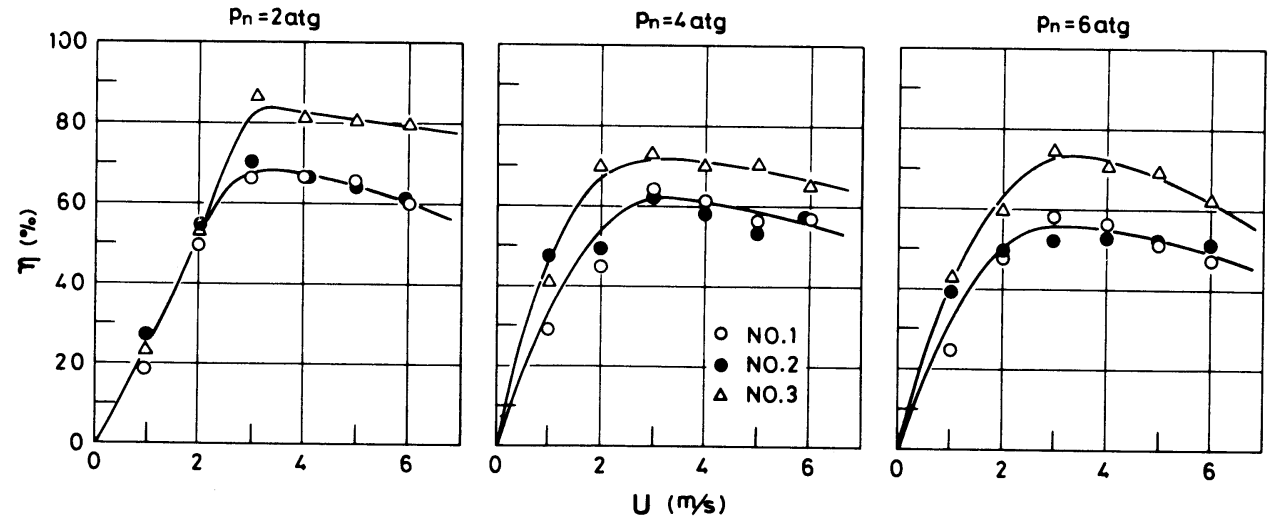

図 9 デミスタの捕集効率 


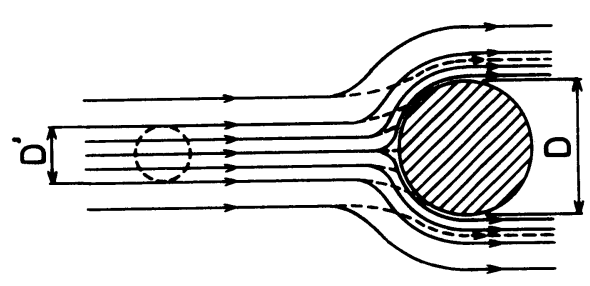

困 10 1本のワイヤの液滴捕集

径を $D$ とすれば $\eta_{\mathrm{d}}^{\prime}$ は $D^{\prime} / D$ で表わされる. この $\eta_{\mathrm{d}}^{\prime}$ の值 はこれまで多数の理論的および実験的研究によって発表 されているが,ここでは図11に示す有名なBrunら ${ }^{9)}$ の線 図を用いる。縦軸が $\eta_{\mathrm{d}}^{\prime}$, 横軸が慣性パラメータ $K_{0}$ で, 無次元数 $\varphi$ をパラメータにしている. $K_{0}$ と $\varphi$ はそれぞれ 次式で定義される.

$$
\begin{aligned}
& K_{0}=\frac{\rho_{\mathrm{p}} D_{\mathrm{p}}^{2} \cdot U}{9 \mu_{\mathrm{a}} D} \\
& \varphi=\frac{R e_{\mathrm{p}}^{2}}{K_{0}}=\frac{9 \rho_{\mathrm{a}} D \cdot U}{\rho_{\mathrm{p}} \cdot \nu_{\mathrm{a}}}
\end{aligned}
$$

ここで, $\rho_{\mathrm{a}}$ : 空気の密度, $D$ : ワイヤ径, $\mu_{\mathrm{a}}$ : 空気 の粘性係数, $\nu_{\mathrm{a}}$ : 空気の動粘性係数, $R e_{\mathrm{p}}$ : 液滴粒子の

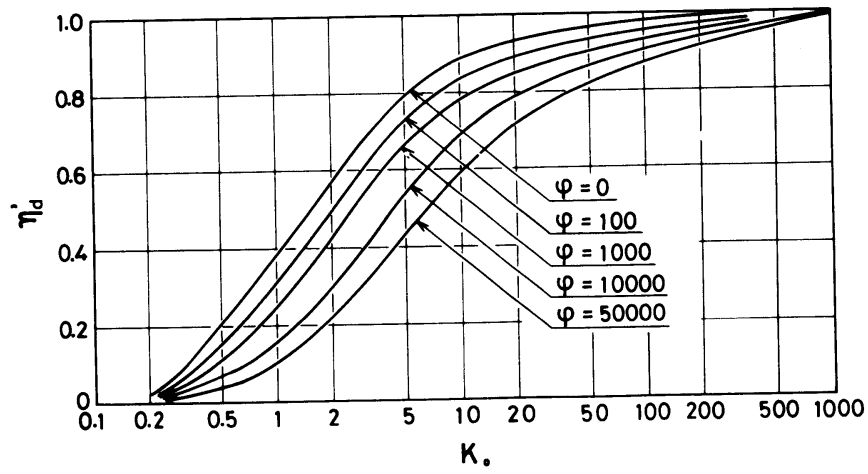

図111本のワイヤに対する慣性パラメータと 粒径捕集効率の関係 (Brun $ら^{9)}$ による)
レイノズル数.

本実験では $\varphi$ の值はきわめて小さく， $\varphi=0$ の効率曲 線を用いることができる.いま, 式(12)から各ワイヤ径 に対して $K_{0}$ を計算し, 図 11 によって 稃を求めた結果 を図 12 に示す. 1 本のワイヤの粒径捕集効率は液滴粒 径亡空気速度が大きいほど，また，ワイヤ径が小さいほ ぞ大きくなることが分る.

この $\eta_{\mathrm{d}}^{\prime}$ を用いて 1 層のデミスタの理論粒径捕集効率 $\eta_{\mathrm{d}}$ を次式加求めた.

$$
\begin{aligned}
& \eta_{\mathrm{d}}=p_{1} \cdot \eta_{\mathrm{d}}^{\prime}\left(\text { Bürkholz らの式 }{ }^{3)}\right) \\
& \eta_{\mathrm{d}}=F p_{1} \eta_{\mathrm{d}}^{\prime}\left(\text { Carpenter らの式 }{ }^{5)}\right)
\end{aligned}
$$

ここで, $F$ は定数 $(=2 / 3)$ である.

図 13 亿本実験の供試デミスタに対する理論粒径捕集 効率を示す. 実線が式(14), 破線が式(15)をそれぞれ 用いて計算した結果である。

デミスタへ流入する液滴の質量ひん度 $f_{\mathrm{p}}$ は既知である からデミスタの理論捕集効率 $\eta_{\text {th }}$ は次式で計算するとと ができる.

$$
\eta_{\mathrm{th}}=1-\sum_{D_{\mathrm{p}}} f_{\mathrm{p}}\left(1-\eta_{\mathrm{d}}\right)
$$

しかし，図 13 による上粒径が約 $40 \mu \mathrm{m}$ 以上の液滴の 理論粒径捕集効率は No. 1 と No. 2 デミスタ に対して $30 \%$ まは $20 \%$ てN, No.3デミス

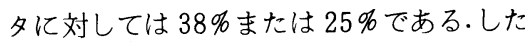
がって，理論捕集効率がこれらの值以上に ならないことは明らかである。本実験で得 られた捕集効率と比較するとかなり差が大 きい.その原因としては次のようなととが 考えられる.

(1)実際にはワイヤのまわりに液膜が生成 されているために液滴の付着が容易になっ ている.

(2)理論式はその式の形から上限值が定ま ってしまう.

(3)理論では液滴粒子径がワイヤ径よりあ 小さいとしているが, 実際には液滴は微粒
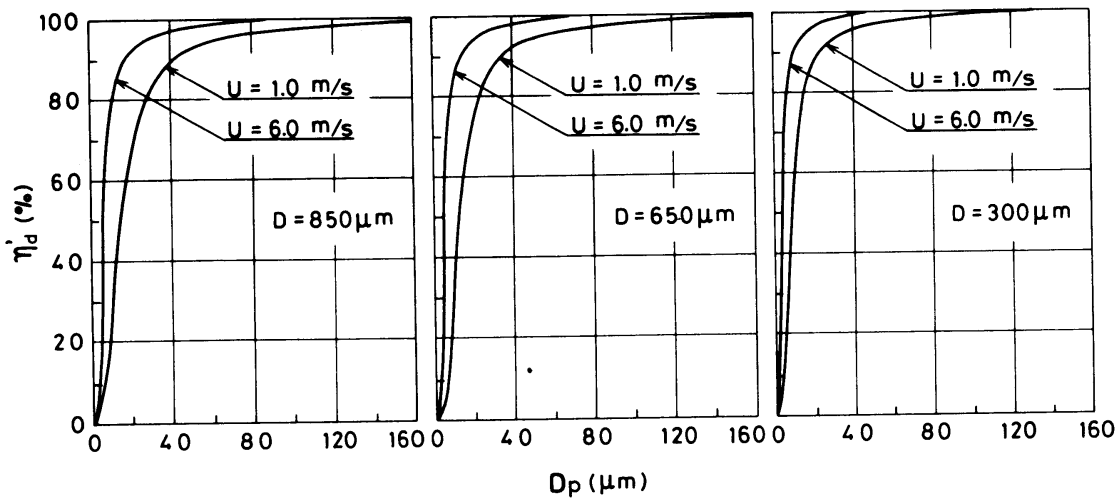

図 121 本のワイヤの粒径捕集効率 


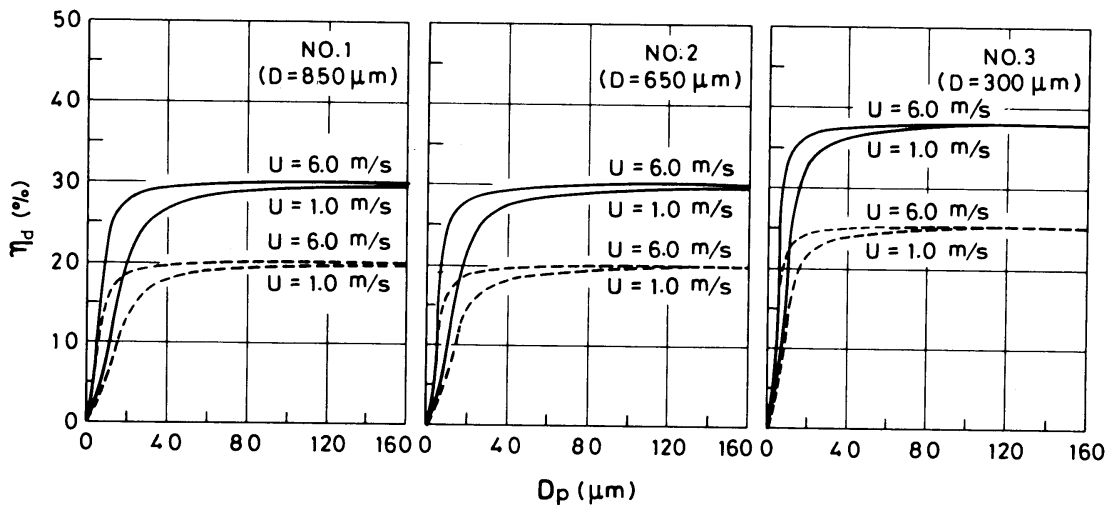

図 13 供試デミスタの理論粒径捕集効率

子だけではない.

(4)理論ではメッシュ間隔の影響や同伴液滴の流量の影 響が入っていない.

3.3 許容空気速度 ワイヤメッシュに付着した 液滴に作用する力は空気速度による力, 重力, 表面張力 の3 種の力で, これらの力のバランスがくずれると液滴 は流下したり再同伴したりする. あし, 空気速度による 力が他の二つの力よりも大きくなると液滴は再同伴され ることになるが, この再同伴の生じない最大の空気速度 を許容空気速度とよぶ. フラッディング等を考慮して水 平に置かれたワイヤメッシュデミスタに対する許容空気 速度 $U_{\mathrm{c}}$ は次式で表わされる.

$$
U_{\mathrm{c}}=c \sqrt{\frac{\rho_{\mathrm{p}}-\rho_{\mathrm{a}}}{\rho_{\mathrm{a}}}}
$$

ここで, $c$ は定数でデミスタの形状や運転条件によっ て種々の値をとる.

いま, 文献 6)に示されている定数 $c$ の值から $U_{\mathrm{c}}$ を計

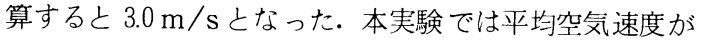

$3.0 \mathrm{~m} / \mathrm{s}$ 以上になるとRosin-Rammler 線図でその分布 の区別ができなくなってくることが示された.

\section{4 ワイヤメッシュデミスタの圧力損失}

ワイヤメッシュデミスタの圧力損失 $\Delta p$ はデミスタの 前方 $140 \mathrm{~mm}$, 後方 $500 \mathrm{~mm}$ の位置に打けるベッッ型マ ノメータで測定した静圧差から，デミスタの無いときの 同じ場所における静圧差を差し引いたものとして定義し た.いずれのデミスタも液滴を噴霧せずに空気のみを流 す乾燥時圧力損失之, 液滴を噴霧したときの圧力損失は 一致しない。一方，同じ空気速度範用でエリミネータの 場合はこの両者の間には全く差は認められなかった 2 . エリミネータはその構造上, 折れ板に付着した液膜が著 しく流路を狭くするということはないが，デミスタの場 合はワイヤメッシュに付着した液滴によりワイヤ径が太 くなったととと同じ効果が生じるとともに, 条件によっ てはメッシュの目を液膜が覆ってしまい流路面積を著し く狭くすることが観察された. 図 14 に乾燥時之噴霧圧 力を変えたときの各種のデミスタに対する珐力損失の測

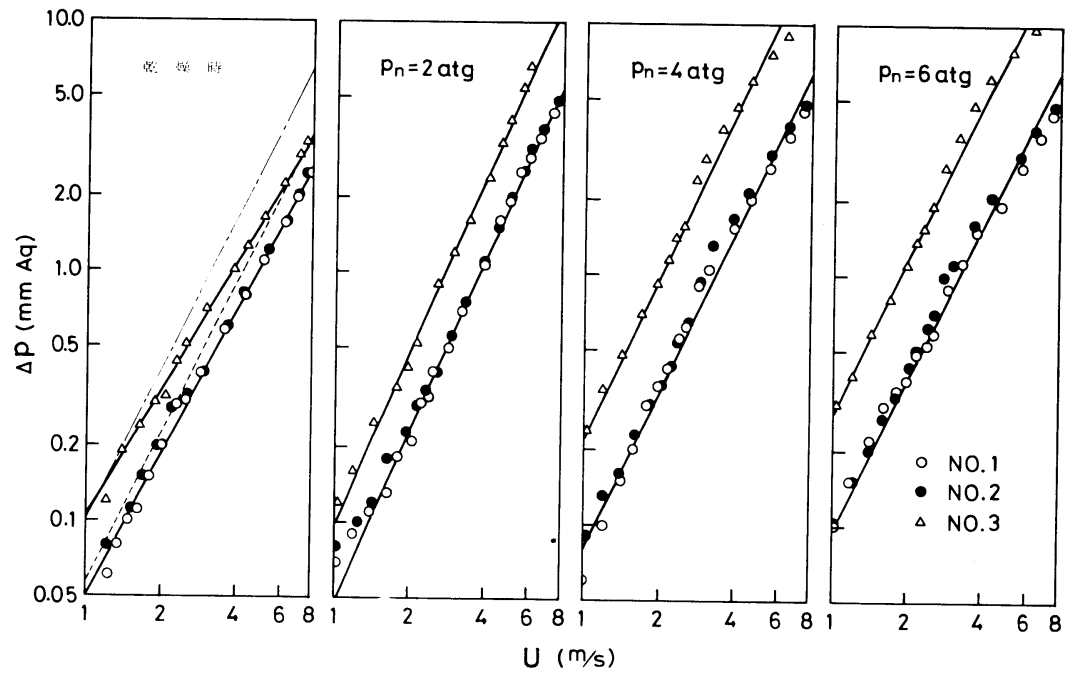

図 14 供試デミスタの圧力損失 
定結果を示す. 縦軸に圧力損失 $\Delta p(\mathrm{mmAq})$, 横軸に平 均空気速度 $U(\mathrm{~m} / \mathrm{s})$ をそれぞれ両対数グラフにとって いる. 全体的に, No.1 とNo.2 デミスタにおいてはNo.2 デミスタの方がわずかに圧力損失が大きい程度で, ほと んど両者は 1 本の直線で表わすことができる. それに対 して, No. 3 デミスタの圧力損失はかなり大きくなって いる. また, 両直線の傾きは乾燥時の場合には少し異な るが, 各噴霧条件に扔いてはお互いにほとんど等しく, 噴霧圧力が大きくなるにつれてわずかに小さくなってい る.

次にデータのばらつきについて考察する．乾燥時と噴 霧压力が $2 \mathrm{atg}$ のきの圧力損失は各デミスタとあによ い直線性を示していることが分る.しかし，噴霧圧力が 4 atg 以上になると平均空気速度の小さい範囲ではよい 直線性を示すが, 平均空気速度が約 $3.0 \mathrm{~m} / \mathrm{s}$ 以上になる とデータのばらつきが目立つ. このように平均空気速度 と噴霧圧力がとあに大になるにつれてデータがばらつく ことは，デミスタに付着する液滴の量が多くなってワイ ヤメッシュの目を覆う液膜が生じては, また, 再同伴さ れることによって消滅するといった具合にデミスタの表 面の状態が変動しやすいためと考えられる．このととは デミスタの捕集効率を考察するうえからあ重要な現象で ある.とのように $p_{\mathrm{n}}$ を一定にして $\Delta p$ とUの関係が得ら れたが, 実際には図 8 に示したように平均空気速度が変 化すると同伴液滴流量む変化する．したがって，㛜密に は各平均空気速度に対して同伴液滴流量が一定になるよ うに噴霧圧力を調整して圧力損失を測定する必要がある.

図 15 は No. 1, No. 2 デミスタとNo. 3 デミスタに対す る圧力損失を噴霧圧力をパラメータにして描き直したあ ので，噴霧圧力すなわち同伴液滴流量の影響は目の細か いNo. 3 デミスタの方に大きくあらわれていることがよ く分る.

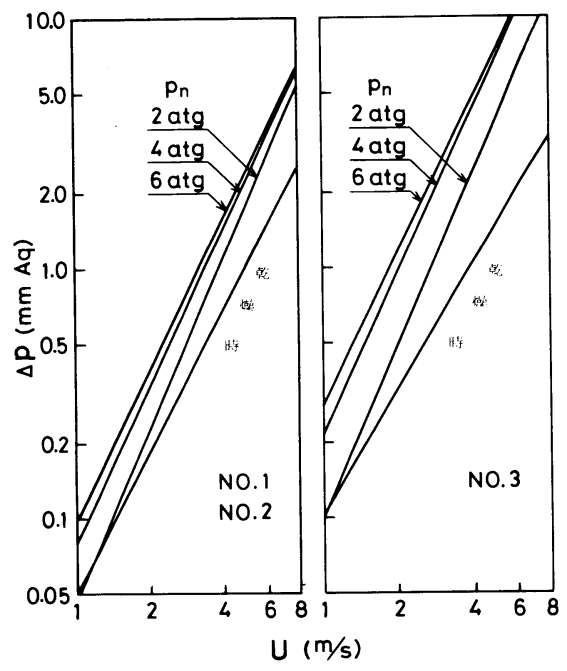

図 15 供試デミスタの圧力損失
エリミネータの場合は, 圧力損失 $\Delta p$ がほぼ完全に平 均空気速度 $U$ の 2 乗に比例するとして圧力損失係数らを 算出することができたが ${ }^{2)}$, このデミスタの場合は, $\Delta p$ がUの $k$ 乗に比例するとして次式かららを求める.

$$
\zeta=\frac{\Delta p}{\rho_{\mathrm{a}} \cdot U^{k} / 2 g}
$$

ここで, $g$ は重力加速度で, 指数 $k$ は直線の傾きから 求める.

表 2 に各デミスタに対する指数 $k$ と圧力損失係数らの 值を示す. 噴霧圧力が 4 atg および 6 atg になると No. 3 デミスタのらはNo. 1 抢よびNo. 2 デミスタのらの約 3 倍にあなっている.

いま, 液滴を噴霧したときの圧力損失と乾燥時の压力 損失との比を圧力損失比と呼び，乙の值を計算すると表 3 のようになる. それぞれ最低值は $U=1.0 \mathrm{~m} / \mathrm{s}$ のさ で, 最高值は $U=6.0 \mathrm{~m} / \mathrm{s}$ のきの值である. 乾燥時の 圧力損失をべースにした比較的一定な損失比を有してい るのはNo. 1 とNo. 2 デミスタに対する $p_{\mathrm{n}}=6$ atg のとき でほぼ乾燥時の 2 倍程度におさまっており, 次いで同じ デミスタの $p_{\mathrm{n}}=4 \mathrm{atg}$ のきである. No. 3 デミスタはメ ッシュの目が小さいために液滴がそこを覆いやすく他の デミスタに比べて圧力損失比はきわめて大きい.

表 2 圧力損失係数

\begin{tabular}{|c|c|c|c|}
\hline デミスタ & 条 件 & $k$ & $\zeta$ \\
\hline \multirow{4}{*}{ No.1 } & 乾燥 時 & 1.899 & 0.7838 \\
& $p_{\mathrm{n}}=2 \mathrm{atg}$ & 2.289 & 0.7683 \\
& 4 & 2.125 & 1.2541 \\
& 6 & 2.045 & 1.5151 \\
\hline \multirow{4}{*}{ No.2 } & 乾燥 時 & 1.899 & 0.8383 \\
& $p_{\mathrm{n}}=2$ atg & 2.289 & 0.8147 \\
& 4 & 2.125 & 1.3438 \\
& 6 & 2.045 & 1.6262 \\
\hline \multirow{4}{*}{ No.3 } & 乾燥時 & 1.694 & 1.6334 \\
& $p_{\mathrm{n}}=2$ atg & 2.289 & 1.3438 \\
& 4 & 2.125 & 3.7781 \\
& 6 & 2.045 & 4.7245 \\
\hline
\end{tabular}

表 3 圧力損失比

\begin{tabular}{|l|c|c|c|c|c|c|}
\hline \multirow{2}{*}{$\begin{array}{r}\text { 压力損 } \\
\text { n }\end{array}$} & \multicolumn{3}{|c|}{ No. 1, No.2 } & \multicolumn{3}{c|}{ No.3 } \\
\cline { 2 - 7 } & 最低值 & 最高値 & 比 & 最低值 & 最高值 & 比 \\
\hline 2 atg & 1.00 & 1.89 & 1.89 & 1.00 & 2.86 & 2.86 \\
4 & 1.64 & 2.30 & 1.40 & 2.19 & 4.79 & 2.19 \\
6 & 1.95 & 2.43 & 1.25 & 2.86 & 5.24 & 1.83 \\
\hline
\end{tabular}

なおデミスタのメッシュの孔を通る流れは面積が急 に狭くなる部分と急に広くなる部分を通るととになる. この流れは板にあけた孔を通る流れに似ているので，管 路中にオリフィス板を置いたときの圧力損失を計算で求 め, デミスタの圧力損失と比較した結果を図 14 の乾燥 時圧力損失に示している. 破線および一点鎖線はそれぞ れNo. 1, No. 2 デミスタおよびNo. 3 デミスタの相対投 
影面積を用いて計算したあのである.オリフィス板とし て計算した結果とデミスタの実験結果とは本空気速度範 囲ではかなりよく合っていることが分る.

\section{4. まと め}

形状の異なる 3 種類の 1 層のデミスタに対して得られ た実験結果を簡潔にまとめると次のようになる。

（1）デミスタ前の液滴の粒度分布は噴霧圧力によって 多少のばらつきはあるが, いずれの場合も平均空気速度 の增加之ともに平均粒径は大きくなり, 分布の幅む広が る. しかし, 平均空気速度が $3.0 \mathrm{~m} / \mathrm{s}$ 以上になると粒度 分布は噴霧ノズルの特性に対応する.

(2) デミスタ後の液滴はデミスタ前の液滴と同様に Rosin-Rammler 分布をしている.

（3）平均空気速度が小さくてもデミスタ後の液滴の最 大粒径はデミスタ前のそれとあまり変らない，速度が大 きくなると再同伴によってデミスタ前の液滴の最大粒径 よりあ大きな液滴が生ずる場合がある.

（4）デミスタ後の液滴のRosin-Rammler 線図はほ上 んどデミスタ前の線図よりも粒径の小さい左側にある。

（5）デミスタ後の液滴の分布指数は平均空気速度に関 係せず一定で, 平均粒径はある飽和点に達する速度にな るまでは増加するがそれ以上は一定である。乙の飽和点 に達するときの空気速度はデミスタ前の同伴液滴の流量 に影響される。

（6）本実験に用いた程度の形状の差ではデミスタの種 類による粒度分布の顕著な影響はあらわれなかった。

（7）デミスタの捕集効率はある平均空気速度までは急 激に大きくなるが，それ以上に速度が大きくなると再同 伴の影響で効率は減少し始める.

（8）平均空気速度が小さい場合,デミスタ前の同伴液 滴の流量が少ないとデミスタの種類による効率の差は見 られないが、流量が多くなると 3 種類とも効率の差が見
られる.しかし，空気速度が大きくなるといずれの同伴 液滴流量の場合あ比表面積が最大であるNo. 3 デミスタ の方が他の 2 種類のデミスタよりあかなり効率は大きく なる。

（9）従来発表されているデミスタの捕集効率の理論式 による值は本実験值よりもかなり小さい。その原因は本 文にのべたように理論には同伴液滴流量の影響が入って いないとと等が考えられる.

（10）デミスタの圧力損失は乾燥時よりも液滴を噴霧し たときの方が大きく，同伴液滴流量が多い程その影響は 強い.

（11）No.1 とNo. 2 デミスタに圧力損失の差は少し見ら れるが, No.3デミスタは他のデミスタよりも圧力損失 係数で 2〜3 倍も大きい. このととから，デミスタの圧力 損失は比表面積によって大きく影響を受けることが分る. （12）デミスタの乾燥時圧力損失は管路内のオリフィス 孔を通過するときの圧力損失によく合っている.

\section{文献}

1) 石谷・中西・杉田・長沢, 舶機誌, 12-6 (1977), 387.

2) 石谷・中西・杉田，舶機誌，15-3 (1980), 244.

3) Bürkholz, A., Müschelknautz, E., Chemie-Ing.-Techn., 44-8 (1972), 503.

4) York, O. H., Chem. Engng. Prog., 50-8 (1954), 421.

5) Carpenter, C. L., Othmer, D. F., A.I.Ch.E. Journal, 1-4 (1955), 549.

6) York, O. H., Poppele, E. W., Chem. Engng. Prog., 59-6 (1963), 45.

7) Bradie, J. K., Dickson, A. N., Proc. Instn. Mech. Engrs., 184-3C (1969), 195.

8) Bürkholz, A., Chemie-Ing.-Techn., $42-21$ (1970), 1314.

9) Brun, R. J., Lewis, W., Perkins, P. J., Serafini, J. S., NACA Report, 1215 (1955), 141. 